\title{
Effects of Drought Stress on Seed Germination and Seedling Growth of Different Maize Varieties
}

\author{
Mingli Liu ${ }^{1}$, Meng $\mathrm{Li}^{2}$, Kaichang $\mathrm{Liu}^{2} \& \mathrm{Na} \mathrm{Sui}^{1}$ \\ ${ }^{1}$ Key Laboratory of Plant Stress Research, College of Life Science, Shandong Normal University, Jinan, P. R. \\ China \\ ${ }^{2}$ Shandong Academy of Agricultural Sciences, Jinan, P. R. China \\ Correspondence: Kaichang Liu, Shandong Academy of Agricultural Sciences, Jinan 250100, P. R. China. E-mail: \\ liukc@saas.ac.cn \\ Na Sui, Key Laboratory of Plant Stress Research, College of Life Science, Shandong Normal University, Jinan \\ 250014, P. R. China. E-mail: suina800101@163.com
}

Received: March 4, 2015 Accepted: March 31, 2015 Online Published: April 15, 2015

doi:10.5539/jas.v7n5p231 URL: http://dx.doi.org/10.5539/jas.v7n5p231

\begin{abstract}
Maize is susceptible to drought stress, especially during germination. The experiment of seed germination and seedling growth of two maize varieties under different concentration of mannitol solution was carried out. Four mannitol concentrations were set: $0,200,400$ and $600 \mathrm{mM}$, and the corresponding solution osmotic potential was: $0,-0.49,-0.99$, and $-1.49 \mathrm{Mpa}$. Results indicated that Zhengdan958 germinated more quickly and in greater numbers than Liansheng15. The germination rate, germination potential, shoot and root fresh weight, shoot and root length of two maize varieties both decreased under drought stress, but they decreased more in Liansheng 15 than in Zhengdan958. However, the germination and vigor index of Zhengdan958 were obviously higher than that of Liansheng 15 under the stress of 200, 400 and $600 \mathrm{mM}$ mannitol. These results showed that the drought resistances of Zhengdan958 was higher than that of Liansheng 15 by having more powerful root system and higher osmotic adjustment ability.
\end{abstract}

Keywords: maize, mannitol stress, germination, drought resistance

\section{Introduction}

Abiotic stresses are governed by various factors, the most prominent is the elevated temperatures and scarcity of water (Pena \& Hughes, 2007; Narusaka et al., 2003). As drought is one of the most important environmental factors affecting plant growth, development and crop yield, considerable progress has been made in understanding the changes in physiological processes caused by drought stress. It has been shown that the physiological responses of plants to drought stress are extremely complex and vary with plant species as well as with the degree and time of the exposure to drought (Evans et al., 1990, 1991; King, 2011). Differences in resistance to drought are known to exist within genotypes of plant species and were found in many studies, e.g. in maize (Martinielio \& Lorenzoni, 1985; Lorens et al., 1987; Grzesiak, 1990; Grzesiak et al., 2012), wheat (Winter et al., 1988; Reynolds et al., 1998; Paknejad et al., 2007), rape seed (Richards \& Thurling, 1978), oat (Larsson \& Go'rny, 1988), coconut (Gomez et al., 2008) and triticale (Royo et al., 2000; Grzesiak et al., 2012). Unusual dry weather conditions adversely affect germination and seedling growth rates thus enhancing cell elongation sensitivity to damages induced under stressed conditions (Taylor et al., 1982; Delachiave \& Pinho, 2003; Hamayun et al., 2010a). Deleterious effects of water stress have been reported in different crops such as tomato (Ragab et al., 2007), soybean (Sakthivelu et al., 2008; Hamayun et al., 2010b), corn (Khodarahmpour, 2011) and citrus (Ben-Hayyim, 1987).

Maize is one of the important crops, which serves as food and corn oil for human consumption, feed for livestock and poultry and raw material for agro-based industries. Expanding populations with greater food and energy needs are increasing demand for greater global maize production. Unfortunately, environmental limitations such as temperature and drought continue to restrain maize production levels as they have in earlier decades and in many areas, which is predicted to worsen with changing climates (Battisti \& Naylor, 2009; Lobell et al., 2011; Mishra \& Cherkauer, 2010). The increasing frequency of dry periods in many regions of the world 
result in the consecutive occurrence of drought on cultivated land (Hu \& Schmidhalter, 2005). In China, maize planted in arid and semi arid area. At present, China's annual maize planting area is around 24 million $\mathrm{hm}^{2}$, of which nearly $2 / 3$ area is dry-land maize. Drought has become an important limiting factors of agricultural production in the world, especially in arid agricultural production. As dry-land crops, corn not only need more water, but also are more sensitive to water stress. Drought is the major cause of our country and around the world maize production low and unstable, generally can be reduced by $20 \%-30 \%$. Therefore, the breeding of new maize varieties with strong drought resistance is one of effective ways for high and stable yield. However, the accurate identification of drought resistance of maize varieties is the basis for breeding drought resistance maize varieties.

In recent years, many scholars have studied the drought mechanism of maize, identification methods and indicators of drought resistance. Wang et al. have studied the germination characters of maize varieties with a hypertonic solution PEG-6000 simulated drought stress. Xu et al. have studied the germination potential, germination rate and utilization efficiency of storage material, amylase activity. Hou et al. have studied the drought resistance in the germination period of maize by hypertonic solution germination, TTC quantitative measurement, seed water absorption detection method with mannitol solution simulated water stress. These methods and indicators reflected the drought resistance of maize varieties from different angles and extent, also see scattered reports on bud seedling stage of maize.

Mannitol is a kind of macromolecule osmotic regulation substances that can't through the cell wall, small toxicity to cells, an ideal material to simulate the soil drought. This experiment with mannitol hypertonic solution simulated water stress and studied the difference of drought resistance on germination and seedling growth of two maize varieties to filter out strong drought resistance varieties, in order to provide theoretical guidance for drought resistance breeding and promotion of maize varieties.

\section{Materials and Methods}

\subsection{Plant Culture and Treatments}

Maize seeds were provided by the shandong academy of agricultural sciences. Dry seeds were stored in a refrigerator at $-4{ }^{\circ} \mathrm{C}$ before being used.

Selecting the grain full, same size, no worm holes maize seeds, $70 \%$ ethanol solution disinfected for 2 min and then rinsed with running water. Each variety seeds germinated in different germination boxes which containing 20 seeds. Each variety sets four concentration: 0, 200, 400 and $600 \mathrm{mM}$ mannitol, three times repeated and the corresponding solution osmotic potential were: $0,-0.49,-0.99$, and $-1.49 \mathrm{Mpa}$. New mannitol solution of the same amount and normal water were replaced every day. The seeds germinated in a glasshouse in the light condition of $14 \mathrm{~h}$ light $/ 10 \mathrm{~h}$ dark. The temperature in the glasshouse was $25^{\circ} \mathrm{C}$ during the day and $20^{\circ} \mathrm{C}$ at night.

\subsection{Germination Rate (\%)}

Observing germination situation of maize seeds every day and the germination rate of seeds was measured by the national seed inspection standards. Computing the final germination rate after germination for seven days. Germination rate was calculated as follows: Germination rate $=($ Germinated seed number/Test seed number $) \times$ $100 \%$

\subsection{Germination Potential}

Germination potential is the index to evaluate the seed germination rate and germination uniformity. Germination potential was calculated as follows: Germination potential $=($ Germinated seed number at germination peak/Test seed number) $\times 100 \%$

\subsection{Germination and Vigor Index of Drought Resistant}

Germination and vigor index of drought resistant were calculated as follows: Seed germination index of drought resistance $=$ seed promptness index under water stress (PIS)/controlled seed promptness index (PIC); Promptness index $\mathrm{PI}=\mathrm{nd}_{2}(1.00)+\mathrm{nd}_{4}(0.75)+\mathrm{nd}_{6}(0.50)+\mathrm{nd}_{8}(0.25) ; \mathrm{nd}_{\mathrm{x}}=$ number of germinated seeds by the $\mathrm{xth}$ day of measurement (Grzesiak et al., 2013).

Seed vigor index of drought resistance $=$ Seed vigor index under water stress (VIS)/Controlled seed vigor index (VIC); Vigor index VI $=\mathrm{PI} \times \mathrm{Sx}$; Sx is the average length of bud for seventh days.

\subsection{Shoot and Root Fresh Weight and Root-Shoot Ratio}

After germination for seven days, seedlings grew consistently were chosen to be cut the root and shoot with a shear and weighed respectively. Root-shoot ratio was calculated as follows: Root-shoot ratio $=$ Root fresh 
weight/Shoot fresh weight.

\subsection{Shoot and Root Length}

After germination of maize seeds for seven days, the shoot and root length were measured with a ruler.

\subsection{Drought Resistance Coefficient}

Drought resistance coefficient can reflect the sensitivity of plants to drought and it was calculated as follows: Drought resistance coefficient $=($ Index value under drought stress/Index value under normal moisture $) \times 100 \%$

\section{Results}

\subsection{Germination Rate during Drought Stress}

The germination of Zhengdan958 was better than Liansheng15 under different mannitol treatment (Figure 1). The germination rate of two maize varieties declined obviously under drought stress. Under $200 \mathrm{mM}$ mannitol treatment, germination percentage of Zhengdan958 and Liansheng15 decreased $1.75 \%$ and $13.46 \%$, respectively. Under $400 \mathrm{mM}$ mannitol treatment, germination percentage of Zhengdan958 and Liansheng15 decreased 28.07 $\%$ and $50.00 \%$, respectively. Under $600 \mathrm{mM}$ mannitol treatment, germination percentage of Zhengdan958 and Liansheng 15 decreased $50.88 \%$ and $75.00 \%$, respectively (Figure 2).
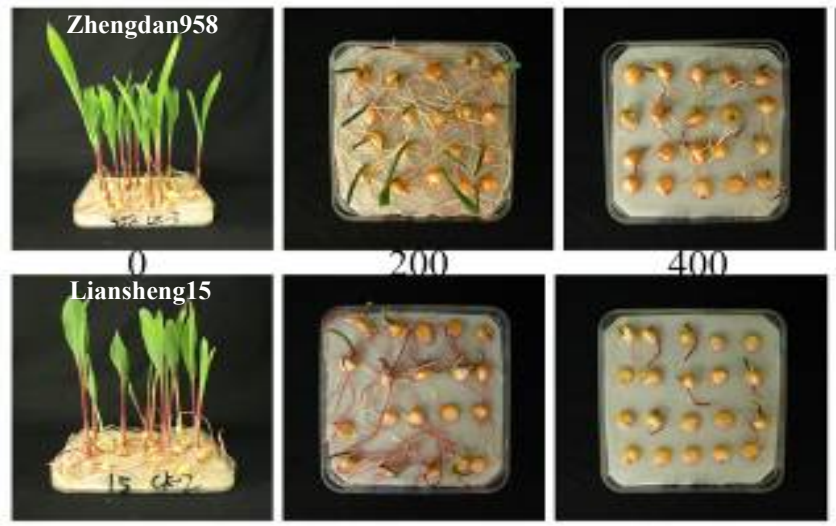

400
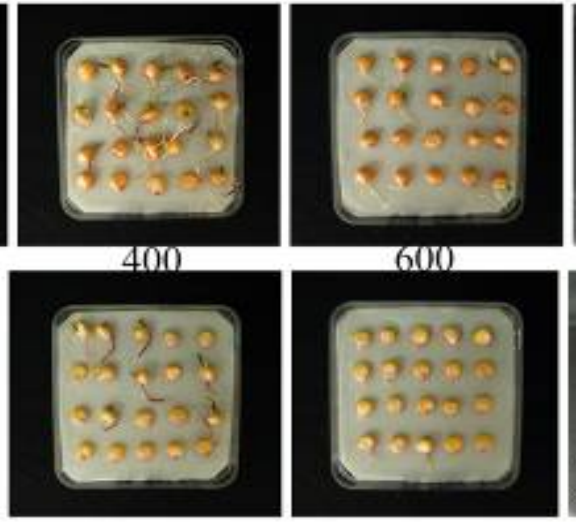

600
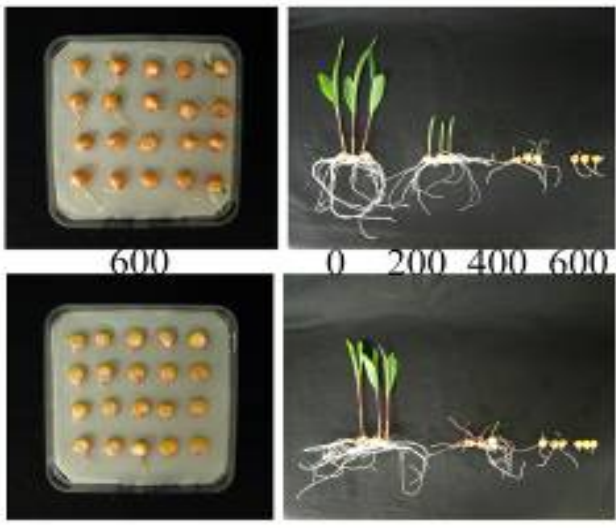

Figure 1. Photos of germination of Zhengdan958 and Liansheng15 under different concentrations of mannitol
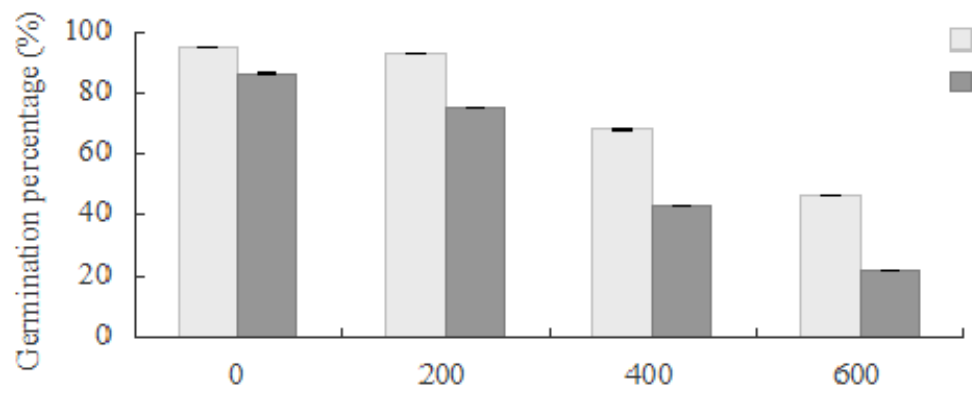

Different mannitol concentration treatment $(\mathrm{mM})$

Figure 2. Germination rate of different maize varieties in response to different concentrations of mannitol. Each point represents the means \pm SD of five measurements on each of five plants $(n=5)$

\subsection{Germination Potential during Drought Stress}

The germination potential of two maize varieties declined significantly under mannitol stress and there was significant difference between different varieties. Under $200 \mathrm{mM}$ mannitol treatment, there was nearly no decrease in germination potential of Zhengdan958, but it decreased $34.62 \%$ in Liansheng15. Under the stress of $600 \mathrm{mM}$ mannitol, the germination potential of Zhengdan958 decreased $67.92 \%$ and the germination potential of Liansheng15 was 0 (Figure 3). 


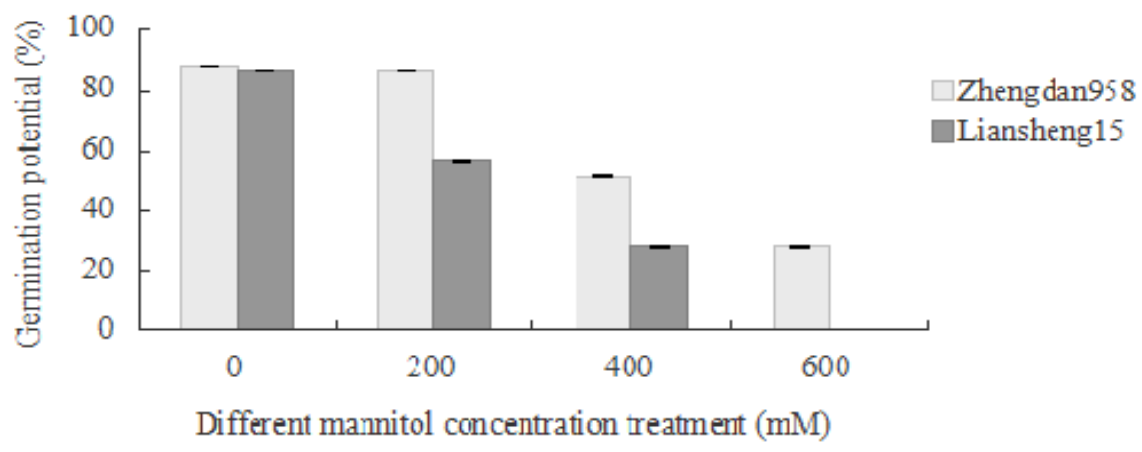

Figure 3. Germination potential of different maize varieties in response to different concentrations of mannitol. Values are means $\pm S D$ of five measurements for each of five plants $(n=5)$

\subsection{Germination and Vigor Index of Drought Resistance}

The germination index (PIS/PIC) and vigor index (VIS/VIC) of drought resistance of the two maize varieties both decreased with the increase of mannitol concentration. The PIS/PIC of Zhengdan958 was higher than Liansheng 15 under the stress of 200, 400 and $600 \mathrm{mM}$ mannitol. The VIS/VIC of Zhengdan958 was also higher than that of Liansheng 15 under 200 and $400 \mathrm{mM}$ mannitol and there was no obvious difference under the stress of $600 \mathrm{mM}$ mannitol (Figures 4 and 5).
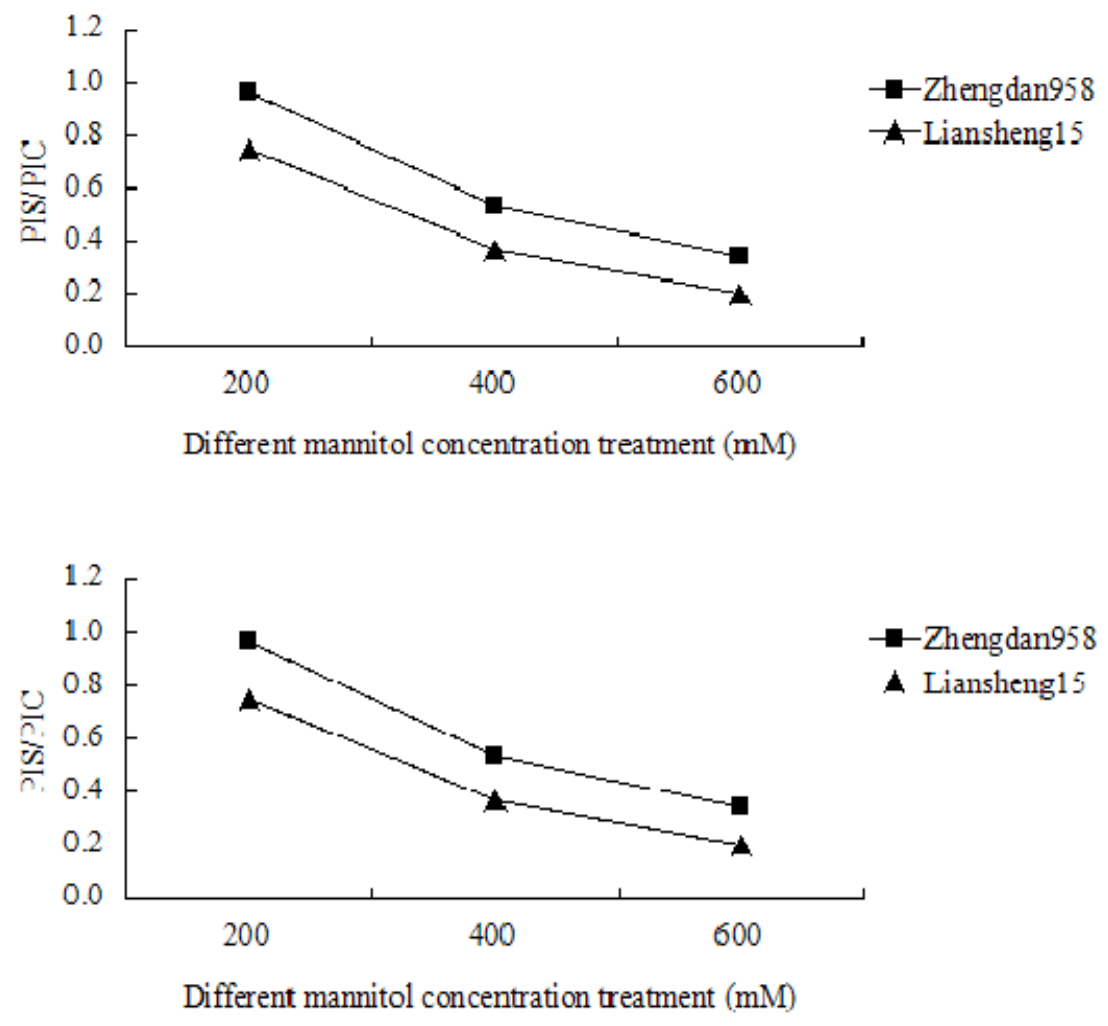

Figure 4. Germination index of drought resistance of different maize varieties in response to different concentrations of mannitol. Data are means of 5 replicates $(n=5) \pm S D$ 


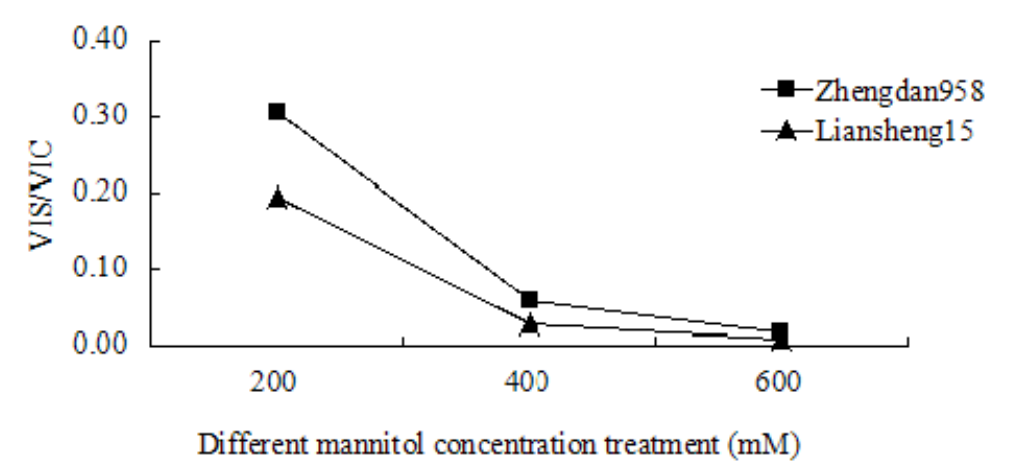

Figure 5. Vigor index of drought resistance of different maize varieties in response to different concentrations of mannitol. Each point represents the means \pm SD of five measurements on each of five plants $(n=5)$

\subsection{Shoot and Root Fresh Weight and Root-Shoot Ratio during Drought Stress}

Shoot and root fresh weight of two maize varieties under drought stress decreased obviously with the increase of mannitol concentration. Under $200 \mathrm{mM}$ mannitol treatment, shoot fresh weight of Zhengdan958 and Liansheng 15 decreased $71.13 \%$ and $79.51 \%$, respectively (Figure 6). Under $400 \mathrm{mM}$ mannitol treatment, shoot fresh weight of Zhengdan958 and Liansheng 15 decreased $90.84 \%$ and $95.55 \%$, respectively. Under $600 \mathrm{mM}$ mannitol treatment, shoot fresh weight of Zhengdan958 and Liansheng15 decreased $95.49 \%$ and $98.36 \%$, respectively. Root fresh weight of Zhengdan958 and Liansheng15 under 200, 400 and $600 \mathrm{mM}$ mannitol treatment decreased $43.73 \%$ and $46.30 \%, 70.28 \%$ and $87.27 \%, 85.87 \%$ and $96.00 \%$, respectively (Figure 7).

The root-shoot ratio of Zhengdan958 increased during mannitol treatment. It increased before $400 \mathrm{mM}$ mannitol treatment and then decreased in Liansheng15 (Figure 8). Root-shoot ratio of Zhengdan958 increased from 0.82 under the control condition to 3.11 under $600 \mathrm{mM}$ mannitol treatment, and the ratio of Liansheng 15 increased from 1.04 under the control condition to 2.15 under $600 \mathrm{mM}$ mannitol treatment.

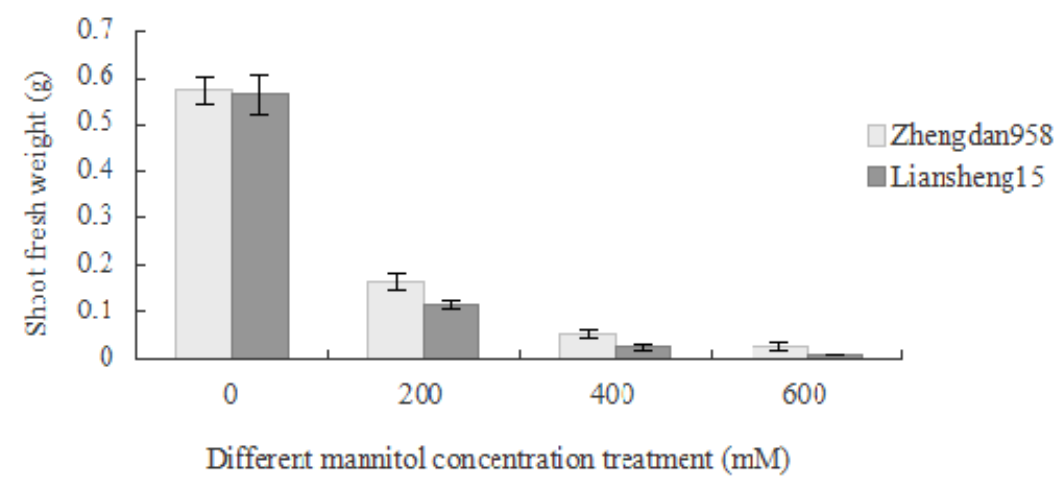

Figure 6. Shoot fresh weight of different maize varieties in response to different concentrations of mannitol. Values are means \pm SD of five measurements for each of five plants $(n=5)$ 


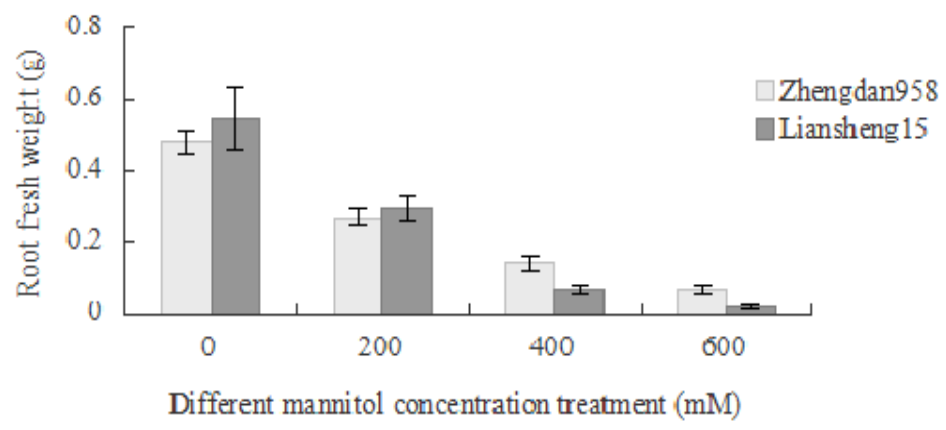

Figure 7. Root fresh weight of different maize varieties in response to different concentrations of mannitol. Data are means of 5 replicates $(n=5) \pm S D$

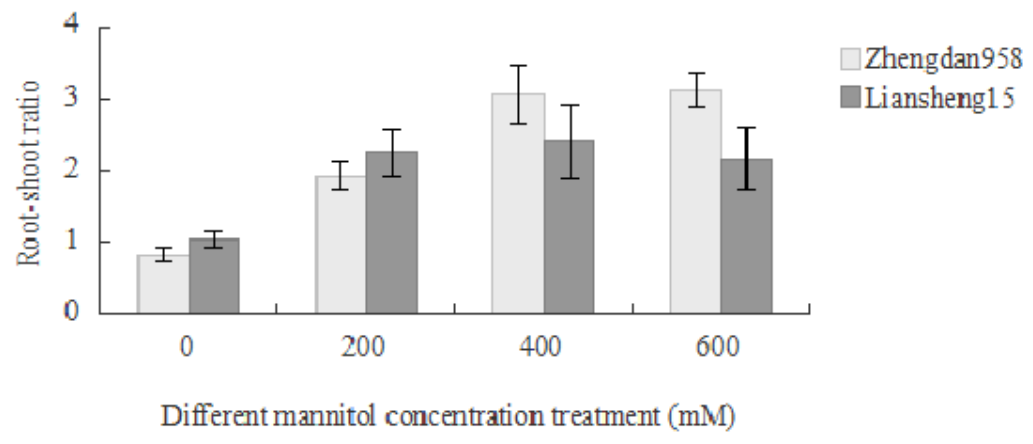

Figure 8. Root-shoot ratio of different maize varieties in response to different concentrations of mannitol. Each point represents the means \pm SD of five measurements on each of five plants $(n=5)$

\subsection{Changes of Shoot and Root Length during Drought Stress}

Shoot and root length of two maize varieties decreased obviously under the stress of 200, 400 and $600 \mathrm{mM}$ mannitol (Figures 9 and 10). Under the stress of 200, 400 and $600 \mathrm{mM}$ mannitol, shoot length of Zhengdan958 decreased $68.17 \%, 88.66 \%$ and $94.33 \%$, respectively. While shoot length of Liansheng 15 under the stress of 200, 400 and $600 \mathrm{mM}$ mannitol decreased $75.20 \%, 92.32 \%$ and $96.80 \%$, respectively (Figure 9). Root length of Zhengdan958 under the stress of 200, 400 and $600 \mathrm{mM}$ mannitol decreased $37.73 \%, 64.53 \%$ and $84.83 \%$, respectively. And root length of Liansheng15 under the stress of 200, 400 and $600 \mathrm{mM}$ mannitol decreased $49.65 \%, 82.39 \%$ and $92.74 \%$, respectively (Figure 10 ).

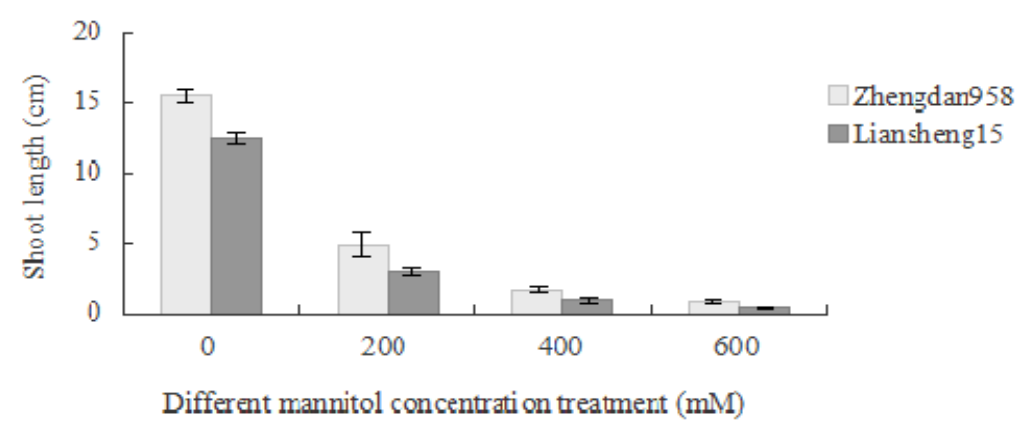

Figure 9. Shoot length of different maize varieties in response to different concentrations of mannitol. Values are means \pm SD of five measurements for each of five plants $(n=5)$ 


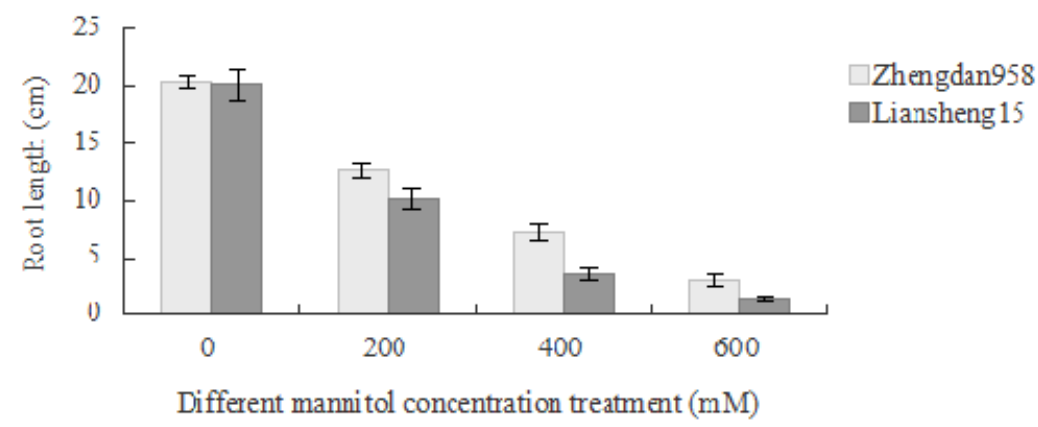

Figure 10. Root length of different maize varieties in response to different concentrations of mannitol. Data are means of 5 replicates $(n=5) \pm S D$

\subsection{Drought Resistance Coefficient}

The drought resistance coefficients of shoot and root fresh weight and length of two maize varieties under drought stress decreased obviously with the increase of mannitol concentration. But the drought resistance coefficients of Zhengdan958 were higher than that of Liansheng15. The drought resistance coefficient of root-shoot ratio of Zhengdan958 increased during mannitol treatment. While the ratio of Liansheng15 increased first and then decreased (Table 1). This showed that the drought resistances of Zhengdan958 was higher than that of Liansheng 15 on seed germination condition.

Table 1. Drought resistance coefficient of two maize varieties under 200, 400 and $600 \mathrm{mM}$ mannitol treatment. Each point represents the means \pm SD of five measurements on each of five plants $(n=5)$

\begin{tabular}{|c|c|c|c|c|c|c|}
\hline Variety & $\begin{array}{l}\text { Mannitol concentration } \\
(\mathrm{mM})\end{array}$ & $\begin{array}{l}\text { Shoot fresh } \\
\text { weight }\end{array}$ & $\begin{array}{l}\text { Root fresh } \\
\text { weight }\end{array}$ & $\begin{array}{l}\text { Root-shoot } \\
\text { ratio }\end{array}$ & Shoot length & Root length \\
\hline \multirow[t]{3}{*}{ Zhengdan958 } & 200 & $0.29^{\mathrm{a}}$ & $0.56^{\mathrm{a}}$ & $2.34^{\mathrm{c}}$ & $0.32^{\mathrm{a}}$ & $0.62^{\mathrm{a}}$ \\
\hline & 400 & $0.09^{\mathrm{b}}$ & $0.30^{\mathrm{b}}$ & $3.74^{\mathrm{ab}}$ & $0.11^{\mathrm{b}}$ & $0.34^{\mathrm{b}}$ \\
\hline & 600 & $0.05^{\mathrm{c}}$ & $0.14^{\mathrm{c}}$ & $3.82^{\mathrm{a}}$ & $0.06^{\mathrm{c}}$ & $0.15^{\mathrm{c}}$ \\
\hline \multirow[t]{3}{*}{ Liansheng15 } & 200 & $0.24^{\mathrm{a}}$ & $0.54^{\mathrm{a}}$ & $2.16^{\mathrm{b}}$ & $0.25^{\mathrm{a}}$ & $0.50^{\mathrm{a}}$ \\
\hline & 400 & $0.06^{\mathrm{b}}$ & $0.13^{\mathrm{b}}$ & $2.33^{\mathrm{a}}$ & $0.08^{\mathrm{b}}$ & $0.18^{\mathrm{b}}$ \\
\hline & 600 & $0.02^{\mathrm{c}}$ & $0.04^{\mathrm{c}}$ & $2.07^{\mathrm{c}}$ & $0.03^{\mathrm{c}}$ & $0.07^{\mathrm{c}}$ \\
\hline
\end{tabular}

\section{Discussion}

Soil drought is one of the most important environmental factors responsible for the limit of maize productivity in many areas of the world. Maize appears very sensitive to drought stress during seedling emergence. Some researches (Grzesiak, 1990; Lorens et al., 1987a, 1987b; Martiniello \& Lorenzoni, 1985; Ristic \& Cass, 1991) confirmed the existence in maize of a wide range of genotypic variability of response to drought. Plants develop different morphological, physiological and biochemical mechanisms which inhibit or remove the harmful effects of drought stresses (Boyer, 1982; Larsson \& Go'rny, 1988; Chaves et al., 2002; Reynolds et al., 1998; Asharaf, 2010). Relatively little research was carried out on the response to drought stress of some plant species. Intragenotypic variability was studied in maize (Martiniello \& Lorenzoni, 1985; Lorens et al., 1987a, 1987b; Evans et al., 1990; Grzesiak, 1990; Ristic \& Cass, 1991). Developing cultivars of maize that can perform well under heat and drought stress is an important goal throughout the world. However, progress in breeding of drought resistant maize genotypes requires future study into physiological mechanisms underlying the responses of maize to water stress (Larsson \& Go'rny, 1988; Richards, 1991). In maize, similarly to other species, genotypic differences in response to soil water deficit were identified with respect to plant physiological characteristics. In the present study, we investigated the effects of drought stress on seeds germination and seedlings growth of two maize varieties.

The germination rate under drought stress can show the germination ability of drought resistance of various 
varieties. In this experiment, we preliminary judged the strength of drought resistance according to the germination rate of two maize varieties under the simulated drought stress with mannitol. The germination rate of two maize varieties declined obviously under drought stress, and there was no significant difference between the two varieties. Under the stress of 200, 400 and $600 \mathrm{mM}$ mannitol, germination percentage of Zhengdan958 was still higher than that of Liansheng15, suggesting that Zhengdan958 had a stronger drought resistance (Figure 2).

Germination potential is a index to evaluate the seed germination rate and germination uniformity. It has been shown that the germination potential of two maize varieties both declined under drought stress. But Liansheng 15 decreased more than that of Zhengdan958 (Figure 3). This suggested that Zhengdan958 germinated more quickly than Liansheng15, showing a stronger drought resistance of Zhengdan958. In addition, the effect of drought stress on the germination potential was greater than germination rate, explaining the greater influence of drought stress on early seed germination. This may be due to the bigger seeds suction influence of Zhengdan958 under drought stress on the early stage of germination.

Vigor index of drought resistance can better reflect the drought resistance and germination characteristics. The germination and vigor index of drought resistance of two maize varieties decreased with the increase of mannitol concentration, but Zhengdan958 decreased less than that of Liansheng15 under the stress of 200, 400 and 600 $\mathrm{mM}$ mannitol (Figures 4 and 5). The seedlings of Zhengdan958 grew better under osmotic stress, which could also be reflected by the seedling fresh weight (Figures 6 and 7) and length (Figures 9 and 10).

Osmotic adjustment is one of main strategies by which plants ensured water uptake during drought stress conditions. Drought resistance coefficient reflects the sensitive degree of plants to drought stress. From our results, the drought resistance coefficients of Zhengdan958 were all higher than that of Liansheng15 (Table 1). Roots is an important absorption organ of plants, developed level of roots is one of the main indexes of drought resistance. From the physiological point of view, a great root-shoot ratio is beneficial to alleviate drought stress. From the experimental results, Zhengdan958 had higher root-shoot ratio under drought stress (Figure 8), suggesting that Zhengdan958 developed powerful root system to fully use of water in deep soil under drought condition, thus showing stronger drought resistance.

\section{Conclusion}

In conclusion, under the same drought stress, the stronger drought resistance varieties which have higher germination and vigor index of drought resistance can still maintain higher germination potential and germination rate. In this experiment, Zhengdan958 germinated in greater numbers and more quickly than Liansheng 15 . And Zhengdan958 also had more powerful root system and stronger ability of osmotic adjustment to ensure seedling establishment in their drought environments, which might be the important reason for higher resistance to drought stress of Zhengdan958.

\section{Acknowledgements}

We are grateful for financial support from the Supporting Plan of National Science and Technology of China (2013BAD07B06), the NSFC (National Natural Science Research Foundation of China (31300205), Natural Science Research Foundation of Shandong (ZR2013CQ009), the Science and Technology Development Projects of Shandong Province (2014GNC113005) and the Program for Scientific research innovation team in colleges and universities of Shandong Province.

\section{References}

Asharaf, M. (2010). Inducing drought tolerance in plants: Recent advances. Biotech Adv, 28, 199-238. http://dx.doi.org/10.1016/j.biotechadv.2009.11.005

Battisti, D. S., \& Naylor, R. L. (2009). Historical warnings of future food insecurity with unprecedented seasonal heat. Science, 323, 240-244. http://dx.doi.org/10.1126/science.1164363

Ben-Hayyim, G. (1987). Relationship between salt tolerance and resistance to polyethylene glycol-induced water stress in cultured citrus. Plant Physiol, 85, 430-433. http://dx.doi.org/10.1104/pp.85.2.430

Boyer, J. S. (1982). Plant productivity and environment. Science, 218, 443-448. http://dx.doi.org/10.1126/science.218.4571.443

Chaves, M. M., Pereira, J. S., Maroco, J., Rodrigues, M. L., Ricardo, C. P. P., Osorio, L. M., ... Pinheiro, C. (2002). How plants cope with water stress in the field? Photosynthesis and growth. Ann Bot, 89, 907-916. http://dx.doi.org/10.1093/aob/mcf105

Delachiave, M. E. A., \& Pinho, S. Z. D. (2003). Germination of Sennaoccidentalis link: seed at different osmotic potential levels. Braz Arch Tech, 46, 163-166. http://dx.doi.org/10.1590/S1516-89132003000200004 
Evans, R. O., Skagss, R. W., \& Sneed, R. E. (1990). Normalized crop susceptibility factors for corn and soybean to excess water stress. Trans ASAE, 33, 1153-1161. http://dx.doi.org/10.13031/2013.31452

Evans, R. O., Skagss, R. W., \& Sneed, R. E. (1991). Stress day index models to predict corn and soybean relative yield under high water table conditions. Trans ASAE, 5, 1997-2005. http://dx.doi.org/10.13031/2013.31829

Gomez, F., Oliva, M. A., Mielke, M. S., Almeida, A. A. F., Leita, H. G., \& Aquino, L. A. (2008). Photosynthetic limitations in leaves of young Brazilian Green Dwarf coconut (Cocos macifera L) "nana" palm under well-watered conditions or recovering from drought stress. Environ Exp Bot, 62, 195-204. http://dx.doi.org/10.1016/j.envexpbot.2007.08.006

Grzesiak, M. T., Marcin'ska, I., Janowiak, F., Rzepka, A., \& Hura, T. (2012). The relationship between seedling growth and grain yield under drought conditions in maize and triticale genotypes. Acta Physiol Plantarum, 34, 1757-1764. http://dx.doi.org/10.1007/s11738-012-0973-3

Grzesiak, M. T., Waligorski, P., Janowiak, F., Marcinska, I., Hura, K., Szczyrek, P., \& Głab, T. (2013). The relations between drought susceptibility index based on grain yield (DSIGY) and key physiological seedling traits in maize and triticale genotypes. Acta Physiol Plant, 35, 549-565. http://dx.doi.org/10.1007/s11738-012-1097-5

Grzesiak, S. (1990). Reaction to drought of inbreds and hybrids of maize (Zea mays L.) as evaluated in field and greenhouse experiments. Maydica, 35, 303-311. Retrieved from http://www.cabdirect.org/abstracts/19901617370.html

Hamayun, M., Khan, S. A., Shinwari, Z. K., Khan, A. L., Ahmad, N., \& Lee, I. (2010b). Effect of polyethylene glycol induced drought stress on physio-hormonal attributes of soybean. Pak J Bot, 42, 977-986. Retrieved from https://scholar.google.com.hk/scholar?q=+Effect + of + polyethylene + glycol+induced + drought + stress + on + physio-hormonal + attributes + of + soybean. \&btnG $=\& h l=z h-C N \&$ as_sdt $=0 \% 2 \mathrm{C} 5$

Hamayun, M., Sohn, E. Y., Khan, S. A., Shinwari, Z. K., Khan, A. L., \& Lee, I. J. (2010a). Silicon alleviates the adverse effects of salinity and drought stress on growth and endogenous plant growth hormones of soybean (Glycine $\max$ L.). Pak $J$ Bot, 42(3), 1713-1722. Retrieved from https://scholar.google.com.hk/scholar?q=Silicon+alleviates+the+adverse+effects + of + salinity + and + drought + stress + on + growth + and + endogenous + plant + growth + hormones + of + soybean $+\% 28$ Glycine + max $+\mathrm{L} \% 29 \& b t$ $\mathrm{nG}=\& \mathrm{hl}=\mathrm{zh}-\mathrm{CN} \& \mathrm{as} \_\mathrm{sdt}=0 \% 2 \mathrm{C} 5$

Hu, Y., \& Schmidhalter, U. (2005). Drought and salinity: A comparison of their effects on mineral nutrition of plants. J Plant Nutr Soil Sci, 168, 541-549. http://dx.doi.org/10.1002/jpln.200420516

Khodarahmpour, Z. (2011). Effect of drought stress induced by polyethylene glycol (PEG) on germination indices in corn (Zea mays L.) hybrids. Afr $J$ Biotech, 10, 18222-18227. Retrieved from http://www.ajol.info/index.php/ajb/article/view/98591

Larsson, S., \& Go'rny, A. G. (1988). Grain yield and drought resistance indices of oat cultivars in field rain shelter and laboratory experiments. $J$ Agron Crop Sci, 161, 277-286. http://dx.doi.org/10.1111/j.1439-037X.1988.tb00668.x

Lobell, D. B., Schlenker, W., \& Costa-Roberts, J. (2011). Climate trends and global crop production since 1980. Science, 333, 616-620. http://dx.doi.org/10.1126/science.1204531

Lorens, G. F., Bennett, J. M., \& Loggale, L. B. (1987). Differences in drought resistance between two corn hybrids. I. Water relations and root length density. Agron J, 79, 802-807. http://dx.doi.org/10.2134/agronj1987.00021962007900050009x

Lorens, G. F., Bennett, J. M., \& Loggale, L. B. (1987b). Differences in drought resistance between two corn hybrids. II. Component analysis and growth rate. Agron J, 79(5), 808-813. http://dx.doi.org/10.2134/agronj1987.00021962007900050009x

Martinielio, P., \& Lorenzoni, C. (1985). Response of maize genotypes to drought tolerance tests. Maydica, 30, 361-370. Retrieved from http://agris.fao.org/agris-search/search.do?recordID=IT876013788

Mishra, V., \& Cherkauer, K. A. (2010). Retrospective droughts in the crop growing season: Implications to corn and soybean yield in the midwestern united states. Agric For Meteorol, 150, 1030-1045. http://dx.doi.org/10.1016/j.agrformet.2010.04.002

Narusaka, Y., Nakashima, K., Shinwari, Z. K., Sakuma, Y., Furihata, T., Abe, H., ... Shinozaki, K. Y. (2003). Interaction between two cis-acting elements, ABRE and DRE, in ABA-dependent expression of 
Arabidopsis rd29A gene in response to dehydration and high salinity stresses. The Plant Journal, 34(2), 137-149. http://dx.doi.org/10.1046/j.1365-313X.2003.01708.x

Paknejad, F., Nasri, M., Moghadam, H. R. T., Zahedi, H., \& Alahmadi, M. F. (2007). Effects of drought stress on chlorophyll fluorescence parameters, chlorophyll content and grain yield of wheat cultivars. J Biol Sci, 7 , 841-847. http://dx.doi.org/10.3923/jbs.2007.841.847

Pena, R. D. L., \& Hughes, J. (2007). Improving vegetable productivity in a variable and changing climate. SAT eJournal, 4, 1-22. Retrieved from http://agropedia.iitk.ac.in/openaccess/sites/default/files/sp1.pdf

Ragab, A. R., Abdel-Raheem, A. T., Kasem, Z. A., Omar, F. D., \& Samera, A. M. (2007). Evaluation of R1 tomato somaclone plants selected under poly ethylene glycol (PEG) treatments. Afr Crop Sci Soc, 8, 2017-2025. Retrieved from http:/www.acss.ws/upload/xml/research/468.pdf

Reynolds, M. P., Singh, R. P., Ibrahim, A., Agech, O. A. A., Larque-Saavedra, A., \& Quick, J. S. (1998). Evaluation physiological traits to complement empirical selection for wheat in warm environments. Euphytica, 100, 84-95. http://dx.doi.org/10.1023/A:1018355906553

Richards, R. A., \& Thurling, N. (1978). Variation between and within species of rapeseed (Brasica campestris and B napus) in response to drought stress. I. Sensitivity at different stages of development. Aust J Agric Res, 29, 469-477. http://dx.doi.org/10.1071/AR9780491

Ristic, Z., \& Cass, D. D. (1991). Leaf anatomy of Zea mays L in response to water shortage and high temperature: a comparison of drought-resistant and drought-sensitive lines. Bot Gaz, 152(2), 173-185. http://dx.doi.org/10.1086/337878

Royo, C., Abaza, M., Bianco, R., \& Moral, L. F. G. (2000). Triticale grain growth and morphometry as affected by drought stress, late sowing and simulated drought stress. Aust J Physiol, 27, 1051-1059. http://dx.doi.org/10.1071/PP99113

Sakthivelu, G., Devi, M. K. A., Giridhar, P., Rajasekaran, T., Ravishankar, G. A., Nedev, T., \& Kosturkova, G. (2008). Drought induced alterations in growth, osmotic potential and in vitro regeneration of soybean cultivars. Genet Appl Plant Physiol, 34, 103-112. Retrieved from http://www.bio21.bas.bg/ippg/bg/wp-content/uploads/2011/06/08_pisa_1-2_103-112.pdf

Taylor, A. G., Moles, J. E., \& Kirkham, N. B. (1982). Germination and seedling growth characteristics of three tomato species affected by water deficits. $J$ Am Soc Hort, 107, 282-285. Retrieved from http://agris.fao.org/agris-search/search.do?recordID=US19830891444

Winter, S. R., Musick, J. T., \& Porter, K. B. (1988). Evaluation of screening techniques for breeding drought

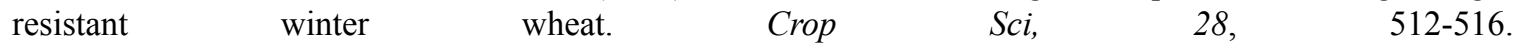
http://dx.doi.org/10.2135/cropsci1988.0011183X002800030018x

\section{Copyrights}

Copyright for this article is retained by the author(s), with first publication rights granted to the journal.

This is an open-access article distributed under the terms and conditions of the Creative Commons Attribution license (http://creativecommons.org/licenses/by/3.0/). 